\title{
Post-hegemonic Regionalism and Sovereignty in Latin America: Optimists, Skeptics, and an Emerging Research Agenda*
}

Thomas Legler**

\section{Introduction}

The defense of sovereignty has had a long tradition in Latin America. Independence struggles were driven to a large extent by the desire of creole elites to be the sovereigns in their own territories. One of the cornerstones of inter-American law has been the protection of Latin American countries from foreign invasions and interventions, first from European powers and then the United States. In the process, a host of legal principles related to the right of self-determination, territorial inviolability, and non-intervention were captured in

\footnotetext{
* Article submitted on October 2nd, 2013 and approved for publication in November 19th, 2013.

** Thomas Legler is a research professor of International Relations at the Universidad Iberoamericana in Mexico City and a member of the Mexican National System of Researchers (SNI, level 2). $\mathrm{He}$ is co-editor of the textbook Introducción a las Relaciones Internacionales: América Latina y la Política Global (México, Oxford University Press, 2013). E-mail: thomas.legler@ibero.mx.
}

CONTEXTO INTERNACIONAL Rio de Janeiro, vol. 35, n² 2, julho/dezembro 2013, p. 325-352. 
juridical instruments such as the Calvo, Drago, and Estrada doctrines, and enshrined in the OAS and UN Charters.

This strong tradition can create the impression of a static conception of sovereignty in the region. It makes it easy to overlook that sovereignty has been subject to both recurring endogenous pressures for modification as well as important variability in its Latin American meanings and practices. Kathryn Sikkink (1996), for example, underlines that historically the social construction of sovereignty in the region has also been linked to strong Latin American traditions of legal thought and political action which have sought to promote the external protection of domestic human rights and democracy. The rise of an inter-American collective-defense-of-democracy regime during the 1990s also raised the issue of whether countries in the region were moving "beyond sovereignty" (FARER, 1996; see also VAN KLAVEREN, 2001). In recent decades, there has also been considerable academic attention to the impact that globalization processes have had on state sovereignty in Latin America (KECK; SIKKINK, 1998; PETRAS, 2003; RADCLIFFE, 2001).

In the new millennium, a growing literature on Latin American and particularly South American regionalisms has made important assumptions and assertions concerning the state of sovereignty in these regions, and the influence thereon of current region-building processes. ${ }^{2}$ With one or two exceptions (see SERBIN, 2011), there have been few explicit and systematic studies of how recent regional trends in Latin America and South America have impacted the meaning and practices of sovereignty. Nonetheless, there is enough out there in terms of passing or ad hoc references in the growing regionalisms literature to identify the parameters of an emerging debate. As I will highlight in this paper, a scholarly debate on this topic is developing between two groups engaged in regionalist analysis: the optimists and the skeptics. ${ }^{3}$ They hold contrasting viewpoints on whether 
Post-hegemonic Regionalism and Sovereignty in Latin America: Optimists, Skeptics...

current regional tendencies associated with the recent rise of regional organizations, such as the Bolivarian Alliance for the Peoples of Our Americas (ALBA), the Community of Latin American and Caribbean States (CELAC), and the Union of South American Nations (UNASUR) are leading to the creation of a new sovereignty regime. Optimists essentially argue that recent changes in regionalism, from the open, U.S.-dominated regionalism of the 1990s to post-liberal, post-neoliberal, or post-hegemonic regionalism in the new millennium, are having a transformative impact on sovereignty. ${ }^{4}$ They suggest that a new sovereignty regime is emerging, particularly in South America, which goes beyond national sovereignty, is linked to the construction of a regional polity, and in which sovereign authority is vested not only in heads of state and government but also in intergovernmental organizations, transnational civil society, and citizens. Skeptics acknowledge that changes in regionalism have occurred, but that they have been accompanied by persistent and traditional sovereignty meanings and practices. That is, evolving regionalisms in Latin America and South America have mutually reinforced national and regional sovereignty, but in ways which have narrowly enhanced presidential authority and projected it regionally through a phenomenon called interpresidentialism.

The truth is that little empirical research has been conducted to determine the current state of sovereignty within its evolving regional parameters. In part this is due to the recent origin of ALBA, CELAC, and UNASUR. As I stress in my concluding remarks, the aforementioned debate can only be resolved through ambitious empirical research, especially in regions such as South America where many of the contending claims are made. Such a research agenda has both significant theoretical implications for understanding Latin America's and South America's unique regional, institutional, and sovereignty patterns, as well as practical ones for understanding the limits and possibilities for regional governance. 
This article is divided into four parts. First, through the notion of sovereignty regimes, I define sovereignty in a way which permits a dynamic analysis of its meanings and practices within changing regional contexts. Accordingly, I present a tripartite conception of sovereign regime: sovereign; space; and authority. In the second section, I examine the optimists' and skeptics' assumptions in the literature on post-hegemonic regionalism regarding the question of sovereignty. In a third section, I employ my aforementioned three-part notion of sovereignty regime to summarize the similarities and differences in the positions of optimists and skeptics. In my concluding remarks I emphasize the need for extensive field research and the theoretical and practical implications of the regionalism-sovereignty nexus.

\section{Sovereignty}

In order to gauge recent trends in post-hegemonic regionalism and sovereignty, it is first necessary to break down the concept of sovereignty in a way which permits its analysis in dynamic terms. Accordingly, in what follows I break down sovereignty into its three core components: the sovereign; territory or space; and, authority. Taken together in different empirical constellations, they constitute distinct sovereignty regimes (AGNEW, 2005). ${ }^{5}$

To paraphrase Hinsley (1986, p. 26), perhaps the most widely accepted definition of sovereignty is the absolute authority of a sovereign within a given political community or territory. At first glance, this would seem a static definition of the concept, when a growing number of scholars remind us that sovereignty is a social construct that is subject to continual change and redefinition in terms of its meanings and practices (BIERSTEKER; WEBER, 1996; BIERSTEKER, 2002; PHILPOTT, 2001). Nonetheless, when we break this definition down into its constituent components, we can develop a diachronic analysis of the concept. 
First, any notion of sovereignty contains implicitly or explicitly some idea of who is the sovereign, that is, the agent or institution that exercises authority. In early modern times, when sovereignty was originally crafted in the context of the treaties of Westphalia, the sovereign was in effect a king/queen or prince/princess or other monarch. Over the centuries, and through historic waves of democratization, who the sovereign is has become democratized in many countries: an elected head of state or government, that is, a president or prime minister. The idea of state sovereignty suggests that the sovereign combines those elected or non-elected officials who govern, together with the bureaucratic apparatus of the state.

It is also feasible that who the sovereign is may also potentially reflect notions of popular sovereignty, as opposed to the aforementioned elite ones. Political authority may be shared with, vested in, or contested by non-state players, including civil society and market agents (business enterprises and multinational corporations). Who the sovereign is may be linked with ideas and values concerning citizenship and political participation. At least rhetorically if not in practice, President Hugo Chávez and his government made frequent statements that the people in Venezuela were sovereign. As this brief summary suggests, considerable historical variation in the social construct of sovereignty may occur along the axis of the identity of the sovereign.

Second, definitions of sovereignty will always contain a spatial or territorial element. Traditionally, the sovereign and sovereign authority have been articulated in national territorial terms and as part of state units. Daniel Philpott (2001) has argued that a series of historic "revolutions in sovereignty" has resulted in the global expansion of the phenomenon of sovereign states, from Westphalian origins in Western Europe, through the nineteenth-century independence of colonies in the Western Hemisphere, up to the postwar decolonization of former colonies in Africa and Asia. 
Supra-nationalism, especially in the case of the European Union, the global and regional expansion of multilateral governance through a proliferation of international organizations, and the rise of transnational activism since the end of World War Two have opened new possibilities in terms of sovereign agency and space. With the pooling and/or delegation of sovereign authority to international organizations which have often become at least partial sovereigns, it is no longer analytically convenient to stick rigidly to state-centric and methodologically nationalist notions of sovereignty. Accordingly, real world sovereignty may also vary historically in terms of its geographic dimensions.

Third, authority is the glue that joins sovereign to territory or space in any concept of sovereignty. Authority has been defined by David Lake (2010, p. 587) as "a social contract in which a governor provides a political order of value to a community in exchange for compliance by the governed with the rules necessary to produce that order." Authority underscores the relational nature of sovereignty. Through the social construction or de-construction of authority, sovereignty entails a central relationship between those who govern or are invested with authority, the sovereign(s), and those who are governed. This core relationship denotes internal sovereignty.

At the same time, there are intricate relations between those within the sphere of authority and those who are outside it. In state-centric analysis, states defend their territorially bound sovereign authority, or autonomy, from outside challengers. These relations entail questions of external sovereignty.

As David Lake (2010) stresses, there is no reason why the analysis of authority should be restricted to state centrism. Those who govern need not necessarily be exclusively governmental players. Intergovernmental and transnational players, or networks which combine diverse state, international, and non-governmental players, may also exercise authority. By extension, authority need not be confined so- 
lely to national territorial spaces; it may be constructed trans-nationally, regionally, and globally. Therefore, supra-nationalism, intergovernmentalism, private, and transnational forms of authority are all historically feasible.

Finally, Hinsley's previously mentioned notion of absolute authority is a misnomer. It is unlikely that historically any sovereign has established complete and total authority over a given territory or space. Internal and external challenges to authority always occur. These may manifest themselves in numerous, almost "normal" ways, from tax evasion, smuggling, and transnational organized crime, to everyday forms of resistance to authorities and insurrection. The problems that many countries in the global South confront establishing their domestic authority while paradoxically enjoying external sovereignty in the interstate system has led to a phenomenon which Robert Jackson (1993) once described as "quasi-states." An ongoing debate exists in terms of the impact that globalization processes have had on state and governmental authority (EVANS, 1997; OHMAE, 1993; RODRIK, 2011; SCHINKEL, 2009; STIGLITZ, 2007; STRANGE, 1998; WEISS, 1998). As Stephen Krasner (1999) has argued, although it is generally valued and upheld as an international organizing principle, sovereignty has been violated so many times in international affairs that it is guilty of "organized hypocrisy." Accordingly, states are not nearly as sovereign as many assume.

The point is that sovereign authority, in whichever geographic space it is exercised, is invariably contested in one way or another from within and from without, and accordingly, is a relative and not an absolute concept. Just as in the case of the definitional elements of sovereign and territory and space, a relative and relational notion of authority facilitates a dynamic analysis of sovereignty in the Latin American context (and elsewhere).

What does sovereignty mean at the regional level, especially in light of recent trends in Latin American and South American regiona- 
lisms? The following section makes clear that an important unresolved debate is taking shape in the scholarly literature on this topic.

\section{Post-Hegemonic Regionalism and Sovereignty: Optimists versus Skeptics}

With few exceptions (SERBIN, 2011), there have been few studies which have looked systematically at the sovereignty question. However, using the aforementioned concepts, it is possible to identify two contending, almost antithetical positions concerning how recent developments in Latin American and South American regionalisms have affected the meaning and practices of sovereignty. On the one side, optimists claim that the creation of multilateral organizations such as ALBA, CELAC, and UNASUR and the regional impulses that they promote represent a potential transformation of sovereignty in alternative, dynamic, and innovative directions. On the other, skeptics argue that these same developments do not represent significant departures from existing meanings and practices, and indeed, may accentuate them.

It should be mentioned that in this stylized portrayal of the debate between optimists and skeptics, there are authors whose analysis combines elements of both camps. For example, Olivier Dabène (2012) calls attention to the oxymoronic character of Latin American regional integration: consistent yet chronically unstable, and resilient in spite of frequent crisis.

\section{Convergences between Optimists and Skeptics}

Before discussing their differences, it is important to point out the significant convergences that exist between optimists and skeptics. 
Post-hegemonic Regionalism and Sovereignty in Latin America: Optimists, Skeptics...

For instance, the point of departure for both is the crisis and decline of open regionalism, once dominant in the Western Hemisphere during the 1990s and into the first years of the new millennium (SANAHUJA, 2010; 2012). The death of the Free Trade Area of the Americas at the 2005 Summit of the Americas in Mar del Plata is generally taken as the symbolic termination of a grand project of hemispheric and open regionalism, and the harbinger of new Latin American and South American regional projects embodied in ALBA, CELAC, and UNASUR. ${ }^{6}$ There is also a consensus that economic liberalism, as captured in the Washington Consensus, has also entered into serious decline as a driving force for regional integration initiatives. Concomitantly, U.S. influence in Latin America also decreased substantially in recent years. Beginning with the election of Hugo Chávez in Venezuela in 1998, a wave of left leaning governments and governing coalitions pressed from within for the end of liberal economic policies and the assertion of economic and political autonomy vis-à-vis the United States.

There is general agreement that when combined, these different domestic, regional, hemispheric, and even global developments have harbored an historic process of the re-definition of regional and sub-regional projects in Latin America and especially South America. It is widely accepted that in contrast to open regionalism, the priorities of regional integration in recent years are not economic, but rather overtly political and social, such that we can now speak of political integration (DIAMINT, 2013; RIGGIROZZI, 2012; RIGGIROZZI; TUSSIE, 2012; ROJAS ARAVENA, 2012; SANAHUJA, 2010; 2012). Moreover, regionalism trends tend now to be characterized best as post-neoliberal (GRUGEL; RIGGIROZZI, 2009; 2012; MACDONALD; RÜCKERT, 2009), post-liberal (SANAHUJA, 2010; 2012), and/or post-hegemonic (RIGGIROZZI; TUSSIE, 2012).

Optimists and pessimists also come together on some points related to the sovereignty implications of recent regional trends. First, in 
contrast to open regionalism's liberalization impulses, post-hegemonic regionalism, as captured in its Bolivarian (ALBA), Latin American and Caribbean (CELAC) and South American (UNASUR) institutional expressions, has been accompanied by the reaffirmation of national sovereignty (MALAMUD, 2013; ROJAS ARAVENA, 2012; SERBIN, 2011). On the one hand, this reassertion has to do with redefining state-market relations in favor of the state as sovereign with restored state authority after neo-liberalism, and with it, strengthening the ability to return to new developmentalist policies and strategies.

On the other hand, it concerns the strengthening of external sovereignty vis-à-vis the United States, and accordingly, the intentional reduction in many Latin American and South American countries of U.S. influence, as well as the re-definition of U.S.-Latin American and U.S.-South American relations. A frequent observation across the literature is that current Latin American regional construction builds on a strong tradition of defensive multilateralism (LEGLER, 2010b; 2011) and defensive regionalism (RIGGIROZZI, 2012; TUSSIE, 2009). In the former case, the recent proliferation of new regional and sub-regional multilateral organizations in Latin America has the common denominator of intentionally excluding the United States and Canada from membership. Organizations such as ALBA are conscious constructs of soft balancing against U.S. power (TORO, 2011). In the case of defensive regionalism, the current social construction of regions in Latin America and South America is intentionally anchored in the creation of regional spaces which increase autonomy in relation to the United States. The quest for autonomy in regional construction, of course, has a long history in Latin America (RIVAROLA PUNTIGLIANO; BRICEÑO-RUIZ, 2013).

Interestingly, although it is not articulated as such in the analyses of optimists and skeptics, revitalized national sovereignty through regional re-definition, constitutes a dual spatial autonomy: national so- 
vereignty is interwoven with and mutually reinforced by regional sovereignty. Sovereign authority at the domestic level within Latin American states is enhanced and protected by the creation of a regional shield against both extra-regional market forces and U.S. power. These convergences notwithstanding, there are important differences that divide optimists and skeptics in terms of how they see post-hegemonic regionalism shaping sovereignty.

\section{Optimists}

The essence of the optimist view is captured in the following words from Pia Riggirozzi and Diana Tussie (2012, p. 2-3):

These processes (regionalism and regionalization) must not simply be seen as ad hoc sub-regional responses to the many crises of neo-liberalism and the collapse of U.S.-led hemispheric leadership, but rather, we argue, as the visible manifestation of a re-politicization of the region giving birth to new polities or regional projects in which states, social movements and leaders interact and construct new understandings of the regional space.

According to Riggirozzi and Tussie (2012, p. 2), the plethora of changes occurring at the regional and sub-regional level in Latin America and especially South America in recent years signal a change of era, instead of simply a period of change (see also ESCOBAR, 2010). According to Cienfuegos and Sanahuja (2010, p. 13), South America as a region appears to be passing through a phase of "great dynamism." An underlying assumption of the optimist position is that particularly South America appears to be undergoing not merely cosmetic changes but a genuine process of the transformation of regional and sub-regional spaces. 
This transformative process has at least four interconnected components: the social construction of a new regional polity; regional "thickening"; regional civil society protagonism; and, the resilience of Latin American regional integration. First, current regionalisms as manifested in and promoted by ALBA, CELAC, and UNASUR, particularly in South America, are producing an authentic regional polity. This is a regional political economy which is redefining state-society and state-market relations away from neo-liberalism toward renewed "statism" and developmentalism. Moreover, the regional polity is being constructed as an autonomous political arena for action, not only for state and intergovernmental players, but also regional civil society (RIGGIROZZI, 2012; TUSSIE, 2009). Importantly, through its new institutional and ideational underpinnings, presumably represented in the form of ALBA, CELAC, and UNASUR, the new regional polity allegedly moves beyond traditional defensive regionalism (RIGGIROZZI, 2012, p. 431). In the words of Riggirozzi (2012, p. 437): "UNASUR is heading towards a coherent institutionalized polity, and potentially supra-nationality a la EU..."

The second transformative assumption of optimists is that the consolidation of a regional polity has been accompanied by regional thickening. Riggirozzi (2012) asserts that UNASUR and ALBA are enhancing "regionness", or an increasing sense of belonging, identity, and inclusion. "Regionness" is also linked to the impression of unprecedented regional unity. This is evidenced, for example, by the strong Latin American (and Caribbean) consensus for the re-inclusion of Cuba in inter-American forums such as the Summits of the Americas; the collective perception of the exhaustion of the U.S.-led war on drugs and the need to find new policy alternatives; and, the recognition for the need to articulate common, autonomous positions and strategies for Latin America in global politics via the creation of CELAC in 2010-2011. Lastly, Rivarola Puntigliano and Briceño-Ruiz (2013, p. 2; see also RIVAROLA PUNTIGLIANO, 2011) 
add that this is the first time in history that South America has been transformed into a single regional player.

Third, the aforementioned points highlight the perception of an enhanced political role for transnational and regional networks of civil society players in region formation and even possibly in governance. Accordingly, the social construction of region is not only presently being achieved from the top down, but from the bottom up. Presumably, this assertion is based on the effervescence of regional and hemispheric activism in recent decades, as exemplified by the collective struggles against the North American Free Trade Agreement and the Free Trade Area of the Americas, the World Social Forums in Brazil, parallel summits at the Summits of the Americas, and the rise of transnational indigenous movement, to name a few.

Finally, optimists view recent events as testimony of the resilience of Latin American integration processes, and not their persistent weakness. Rivarola Puntigliano and Briceño-Ruiz (2013) emphasize that Latin America has a rich, continuous history of regional integration distinguished by three main characteristics: the quest for autonomy; a common cultural identity; and, the motivation of economic and social development.

\section{Skeptics}

Skeptics take issue with all four of the key assumptions made by optimists regarding regional transformation identified above: the birth of a new regional polity and a single regional player; regional thickening; the influence of networks of non-state players, and, the resilience of regional integration. In an overall sense, whereas optimists claim that dramatic changes of late have led to a new era in regionalisms, skeptics underline the persistence and continuity of old political practices and institutional patterns. Moreover, diversity and fragmentation of experiences persists. 
First, skeptics are critical about the notion of an emerging regional polity. Although there may be some important post-neoliberal political economy trends which favor the return of the state and developmentalism, they offer an institutional critique of Latin American and South American regionalism. That is, ALBA, CELAC, and UNASUR thus far are at best hollow institutional shells void of substantive multilateralism, and to which leaders are reluctant to delegate real authority (see DABÈNE, 2012; DIAMINT, 2013; HIRST, 2009; LEGLER, 2010a; 2010b; 2011; LEGLER; SANTA-CRUZ, 2011; SANAHUJA, 2010; SERBIN, 2010). If a regional polity is emerging, it is an exclusive interpresidential space (MALAMUD, 2013; MALAMUD; GARDINI, 2012). Region has become a "niche" for presidential initiative (DIAMINT, 2013). Regional politics are best characterized not as transnational or supranational, but as consistent with a tradition of interpresidential concertación, or coordination and dialogue (MERKE, 2013). Given that summit diplomacy is the preferred regional mechanism for presidential participation in regional politics (see CUMBRES..., 2005; JARQUE; QUENAN, 2009; ROJAS ARAVENA, 2000; ROJAS ARAVENA; MILET, 1998), any regional political arena that is created is episodic rather than sustained and institutionalized. Importantly, rather than the creation of a single, coherent regional space, region inflation is leading to the fragmentation or segmentation of regional spaces (MALAMUD; GARDINI, 2012).

Second, skeptics also question whether regional thickening has occurred. "Regionness" in Latin America and South America is anemic in terms of both economic integration and regional identity formation. Economic integration, especially as measured in terms of intra-regional trade flows and in comparison with the European Union, has been weak (BURGES, 2005; MALAMUD, 2013; MALAMUD; GARDINI, 2012; RUEDA-JUNQUERA, 2009). In terms of collective identity, Thomas Legler (2010b) asserts that Latin America's new 
Post-hegemonic Regionalism and Sovereignty in Latin America: Optimists, Skeptics...

regional and subregional multilateral institutions lack a proper bonding agent. Rud Diamint (2013, p. 74) writes that the idealized vision of a South American identity that supposedly underpins UNASUR is not shared equally among its member states. In contrast to Escobar's (2010) optimistic analysis, Jorge Volpi (2009) questions provocatively whether Latin America even exists at present as a coherent, collective identity. Skeptics would argue that the proliferation of regional experiments in recent years has been due more to shallow elitist, presidentialist, and top-down political projects, rather than because of groundswell popular identification with shared notions of Latin America or South America from below.

Third, post-hegemonic regionalism is not leading to the empowerment of networks of non-state actors. Instead, regionalist trends reflect a pronounced democratic deficit (SERBIN, 2012a; 2012b). It is telling, for instance, that despite its rhetoric of popular participation, ALBA overwhelmingly promotes presidential authority in regional politics and decision-making.

Finally, according to a skeptical interpretation, the historic resilience of Latin American integration efforts must be reconciled with a certain superficiality of current initiatives. Dabène (2012), for example, observes that a trend of integration a la carte exists today, in which various regional and sub-regional arrangements have enshrined the prerogative of countries to endorse selectively their level of commitment to integration schemes. Furthermore, countries such as Brazil engage in an instrumental regionalism, promoting regional arrangements such as MERCOSUR or UNASUR to advance its extra-regional and global ambitions, and not necessarily because of a heartfelt interest in strengthening regional polities and identities. Similarly, from a power politics perspective, Mexico championed the creation of CELAC to counter its exclusion from the South American space caused by UNASUR's creation. Chile, Colombia, Mexico, and Peru recently launched the Pacific Alliance as a trans-regional initiative 
which has trade and investment promotion as its official raison d'être, but which also counterbalances Brazilian power in South America. These impressions contrast sharply with the idea of growing unity of purpose and commitment among the participating states in post-hegemonic regionalism.

\section{Optimists versus Skeptics on Sovereignty: Sovereigns, Space, and Authority}

Returning to my earlier conceptual discussion of sovereignty, the positions of optimists and skeptics with respect to the sovereignty tendencies of post-hegemonic regionalism can be compared and contrasted along three lines: who is the sovereign; the territory or space involved; and the forms of authority that result. Figure 1 summarizes the two antithetical viewpoints.

With respect to which agents are sovereign, optimists claim that democratically elected presidents exercise sovereignty as the expression of popular will, both at the state and regional level. Nonetheless, they also give the impression that networks of non-state players may also be enjoying empowerment, such that we may increasingly be able to speak of a transnational sovereign and popular sovereignty. On the contrary, skeptics perceive current regional trends as strengthening the hand of heads of state, both individually and collectively, at the regional level. Regional politics is almost exclusively the domain of presidents.

In terms of space and/or territory, optimists and skeptics come together in their assessment that post-hegemonic regionalism is strengthening national sovereign spaces. Additionally, regional trends in Latin America and particularly South America are promoting a dual spatial autonomy or sovereignty. That is, interconnected autonomous political spaces are being simultaneously constructed at the domestic 
and regional spaces vis-à-vis the United States and to a lesser extent the social forces of globalization. The convergence ends here, though. Whereas optimists posit that a regional polity and transnational arena for action are in the making, skeptics see only the construction of privileged, elite, interpresidential spaces which are fragmented and lack institutionalization and continuity.

Optimists suggest that a combination of interlinked authority forms is arising: state, intergovernmental, transnational or networked, and potentially supranational. Skeptics argue that state authority at the national level and hyper-presidentialism and collective presidentialism at the regional level are mutually reinforcing. Since multilateral institutions and complex or networked multilateralism are so weak, they perceive very little intergovernmentalism, but rather, regional institutional platforms and spaces for political dialogue privileging presidential activism.

In sum, optimists suggest that a novel sovereignty regime may be in the process of construction: South American popular sovereignty. For their part, skeptics counter that existing sovereignty meanings and practices persist, albeit with a new twist: the regional projection of presidential authority, or executive sovereignty (on executive sovereignty, see COOPER; LEGLER, 2006; LEGLER, 2012).

\section{oncluding Remarks: Regionalism, Sovereignty, and overnance}

Optimists suggest that thanks to post-hegemonic regionalism, and its manifestations in ALBA, CELAC, and UNASUR, a new sovereignty regime may be in the making, especially in South America, with enhanced popular sovereignty within a new regional polity. Skeptics 


\section{Thomas Legler}

\section{Figure 1}

The Impact of Post-Hegemonic Regionalism on Sovereignty

\begin{tabular}{|c|c|c|}
\hline $\begin{array}{l}\text { Analytical Elements } \\
\text { of Sovereignty }\end{array}$ & OPTIMISTS & SKEPTICS \\
\hline Sovereign (Agency) & $\begin{array}{l}\text { - Heads of state } \\
\text { - Transnational networks } \\
\text { - Popular sovereignty }\end{array}$ & $\begin{array}{l}\text { - Heads of state } \\
\text { - nterpresidentialism }\end{array}$ \\
\hline Territory/Space & $\begin{array}{l}\text { - National sovereignty } \\
\text { - Dual spatial autonomy vis-à-vis } \\
\text { United States (national and regional } \\
\text { sovereignty) } \\
\text { - Construction of a regional polity, } \\
\text { especially in South America } \\
\text { - Regional and sub-regional spaces } \\
\text { as transnational 'arenas for action' }\end{array}$ & $\begin{array}{l}\text { - National sovereignty } \\
\text { - Dual spatial autonomy } \\
\text { vis-à-vis United States } \\
\text { (national and regional } \\
\text { sovereignty) } \\
\text { - Interpresidential spaces }\end{array}$ \\
\hline Authority & $\begin{array}{l}\text { - State } \\
\text { - Intergovernmentalism } \\
\text { - Trans-nationalism and/or } \\
\text { networked authority } \\
\text { - Potential Supra-nationalism }\end{array}$ & $\begin{array}{l}\text { - State } \\
\text { - (Hyper-)presidentialism } \\
\text { - Interpresidentialism or } \\
\text { collective presidentialism }\end{array}$ \\
\hline Summary & $\begin{array}{l}\text { - South American popular } \\
\text { sovereignty as an emerging } \\
\text { sovereignty regime }\end{array}$ & $\begin{array}{l}\text { - Continuation of existing } \\
\text { sovereignty regime with } \\
\text { regional extension of } \\
\text { executive sovereignty }\end{array}$ \\
\hline
\end{tabular}

challenge that apart from unprecedented presidential and interpresidential authority at the regional level, there has been little evident transformation in the agency, spatial, and authority dimensions of sovereignty in Latin America and South America.

With ALBA, CELAC, and UNASUR not even ten years old yet, and current regional trends still in redefinition, it is far too soon to decide the outcome of this debate between optimists and pessimists. ${ }^{7}$ One message is clear: this debate will only be resolved through extensive, careful, and painstaking empirical research. Scholars of Latin American and South American regionalism need to get out of the office and into the field to conduct interviews with key informants, from na- 
Post-hegemonic Regionalism and Sovereignty in Latin America: Optimists, Skeptics...

tional leaders and diplomats to transnational and regional activists, as well as ordinary citizens.

The regionalism-sovereignty nexus opens a broad research agenda. Is a new regional polity emerging in places like South America? Is there more continuity or change in the political and institutional tendencies of post-hegemonic regionalism? Why are Latin American political elites so reluctant to delegate authority and construct their own strong international institutions? Are non-state players and citizens increasing their role in regional politics in terms of the contestation and possible transformation of existing sovereign authority? Taking into consideration that supra-nationalism, legalization, substantive and networked multilateralism are all relatively recent additions to the long history of global politics, under what specific conditions might Latin America leaders promote similar institutional and authority trends in their regional spaces? How much regionalization or regional thickening is really occurring in regions such as South America and why?

This research agenda has at least two broader implications. First, in theoretical terms, Latin American-European Union comparisons appear to have only limited applicability for understanding what is going on in Latin America and South America. As Miles Kahler and David Lake (2009) observe, supra-nationalism a la European Union is the exception to the rule in terms of patterns of authority beyond the state in global politics. Similarly, Latin American and South American experiences seem to defy universalist logic as found in neoliberal institutionalist analyses of international institutions, with their emphasis on transaction costs, collective action problems, information flows, and the like. That is, the apparent benefits of creating strong, viable international institutions with substantial delegated or pooled state authority seem to be consistently lost on the region's key decision-makers, because as of yet there are few if any of this type of regional multilateral institutions in existence. This reinforces the sui gene- 
ris character of the politics of regionalism and institution-building in the region. An important theoretical implication seems to be therefore that regions matter in explaining this state of affairs (ACHARYA, 2009; ACHARYA and JOHNSTON, 2007; KATZENSTEIN, 2005). Given the seemingly limited or problematic applicability of theoretical and conceptual tools fashioned by intellectuals in other empirical contexts, Latin American scholars therefore need to move beyond describing trends and patterns in regional politics and sovereignty to theorizing much more why and how they occur, persist, or are transformed.

The second implication has to do with praxis. Through its emphasis on authority, sovereignty analysis can tell us a lot about "real world" regional governance patterns and possibilities. Following the work of James Rosenau (2002), global and regional governance involve the construction of spheres of authority that transcend national territorial boundaries. Authority is the element that connects sovereignty meanings and practices with real existing governance. Kahler and Lake (2009) remind us that the absence of supranational authority does not mean that governance is not occurring beyond the state. The assumption that supra-nationalism is the only alternative to national forms of governance blinds us from seeing other governance possibilities that might exist, such as more vertical or networked forms that extend authority spatially through the power of hegemons like the United States previously, or combinations of interstate and/or transnational players currently. Consequently, if supra-nationalism is absent in Latin America, we need to understand better what specific, real forms of governance are being practiced in regions such as South America. Moreover, if Latin American political elites persistently construct non-supranational forms of regional governance, it would be immensely helpful to ascertain whether these configurations are equally effective or inferior to supra-nationalism and strong international institutions for regional problem-solving. We have barely 
Post-hegemonic Regionalism and Sovereignty in Latin America: Optimists, Skeptics...

scratched the surface in terms of our knowledge of the limits and potential of different forms of regional governance, intricately linked with regionalism and sovereignty trends in the region.

\section{Notes}

1. The author would like to thank the two anonymous reviewers and Sean Burges for their feedback. Any shortcomings in the analysis are of course the author's responsibility.

2. Although it has proven a highly contentious concept, partially paraphrasing Hettne (2005, p. 545), regionalism can be loosely defined as a highly politicized tendency to organize the world in terms of regions, involving potentially both state and non-state players, as well as diverse political, economic, cultural, social, identity, and other dimensions.

3. I hesitate to use the term pessimists and therefore prefer the etiquette skeptics. My labeling exercise is a question of degree. The scholars who are critical of current regionalist currents in Latin America and South America are not opposed to deeper integration and "thicker" regionalism. On the contrary, there is a general view that increased Latin American autonomy, cooperation, integration, and unity are all desirable. These scholars are skeptical that current trends are such a radical departure from existing practices and patterns of sovereignty.

4. Although I recognize the merits of all three labels, post-liberal, post-neoliberal, and post-hegemonic regionalism, more due to space constraints than anything, I limit myself to the use of the latter term. Post-hegemonic regionalism (RIGGIROZZI, 2012; RIGGIROZZI; TUSSIE, 2012) overlaps considerably with the other two concepts and explicitly acknowledges post(neo-)liberal directions in various contemporary Latin American and South American regionalisms.

5. It is worth noting that Agnew (2005) breaks down sovereignty regimes into two components: state authority and political territoriality. This conception, accordingly, is state-centric. I subdivide sovereignty regimes into three elements, in order to leave open diverse possibilities in terms of sovereign agency, that is, for who is the sovereign; what is the space involved; and what forms of authority may ensue. 


\section{Thomas Legler}

6. It is important to acknowledge that ALBA, CELAC, and UNASUR are distinct organizations with their own unique characteristics and mandates, especially in relation to regional tendencies. ALBA promotes a regional identity linked to the notion of "América" with strong ideological connections to Twenty-First Century Socialism, and an intentionally antagonistic and confrontational orientation vis-à-vis the United States (see ALTMANN BORBÓN, 2011; TORO, 2011). CELAC establishes even more diffuse and heterogeneous yet more inclusive regional parameters, Latin America and the Caribbean, and establishes an ideologically pluralistic space for political coordination and dialogue (see ROJAS ARAVENA, 2012). UNASUR, of course, helps carve out a South American regional space which is also ideologically pluralistic (see SANAHUJA, 2012). Nonetheless, as I discuss in these pages, optimists and skeptics suggest important common threads among the three regional institutions in terms of their links to sovereignty.

7. It is worth noting that changes are occurring so quickly in terms of regional tendencies that the literature discussed in this article has not even begun to evaluate what the implications are of the new regional arrangement, the Pacific Alliance, constituted by Chile, Colombia, Mexico, and Peru, as well as possibly Costa Rica, Panama, and even Uruguay, for our understanding of post-hegemonic regionalism(s), and the regionalism-sovereignty nexus. The Pacific Alliance, with its emphasis on trade promotion, investment, and expanding commercial ties with Asia-Pacific, seems to hearken back to earlier open or new regionalism in Latin America. The Pacific Alliance phenomenon further reinforces the case for substantial field research on this topic.

\section{References}

ACHARYA, Amitav. Whose Ideas Matter? Agency and Power in Asian Regionalism. Ithaca: Cornell University Press, 2009.

; JOHNSTON, Alastair Iain (Ed.). Crafting Cooperation: Regional International Institutions in Comparative Perspective. Cambridge, UK: Cambridge University Press, 2007.

AGNEW, John. Sovereignty Regimes: Territoriality and State Authority in Contemporary World Politics. Annals of the Association of American Geographers, v. 95, n. 2, p. 437-461, 2005. 
Post-hegemonic Regionalism and Sovereignty in Latin America: Optimists, Skeptics...

ALTMANN BORBÓN, Josette. (Ed.) ALBA: ¿Una nueva forma de integración regional? Buenos Aires: Teseoy FLACSO, 2011.

BIERSTEKER, Thomas J. State, Sovereignty and Territory. In: CARLSNAES, W.; RISSE, T.; SIMMONS, B. A. (Ed.). Handbook of International Relations. London: Sage, 2002. p. 157-176.

; WEBER, Cynthia (Ed.). State Sovereignty as Social Construct. Cambridge, UK: Cambridge University Press, 1996.

BURGES, Sean W. Bounded by the Reality of Trade: Practical Limits to a South American Region. Cambridge Review of International Affairs, v. 18, n. 3, p. 437-454, 2005.

CIENFUEGOS, Manuel; SANAHUJA, José Antonio (Ed.). Una región en construcción. In: . UNASUR y la integración en América del Sur. Barcelona: CIDOB, 2010.

COOPER, Andrew F; LEGLER, Thomas. Intervention without Intervening? The OAS Defense and Promotion of Democracy in the Americas. New York: Palgrave Macmillan, 2006.

CUMBRES presidenciales (número especial). América Latina Hoy, n. 40, 2005.

DABÈNE, Olivier. Consistency and Resilience through Cycles of Repoliticization. In: RIGGIROZZI, P.; TUSSIE, D. (Ed.). The Rise of Post-Hegemonic Regionalism. Dordrecht: Springer, 2012. p. 41-64.

DIAMINT, Rut. Regionalismo y posicionamiento suramericano: UNASUR y ALBA. Revista CIDOB d'Afers Internacionals, n. 101, p. 55-80, 2013.

ESCOBAR, Arturo. Latin America at a Crossroads: Alternative Modernizations, Post-liberalism, or Post-development? Cultural Studies, v. 24, n. 1, p. 1-65, 2010.

EVANS, Peter. The Eclipse of the State? World Politics, v. 50, n. 1, p. 62-87, 1997.

FARER, Tom J. (Ed.). Beyond Sovereignty: Collectively Defending Democracy in the Americas. Baltimore: Johns Hopkins University Press, 1996.

GRUGEL, Jean; RIGGIROZZI, Pía (Ed.). Governance after Neo-liberalism in Latin America. Basingstoke \& New York: Palgrave Macmillan, 2009. 


\section{Thomas Legler}

Post-neo-liberalism in Latin America: Rebuilding and Reclaiming the State after Crisis. Development and Change, v. 43, n. 1, p. 1-21, 2012.

HETTNE, Björn. Beyond the "New" Regionalism. New Political Economy, v. 10 , n. 4 , p. 543-571, 2005.

HINSLEY, Francis Harry. Sovereignty. 2nd ed. Cambridge, UK: Cambridge University Press, 1986.

HIRST, Mónica. América Latina: méritos del regionalismo anárquico. El Clarín, 5 Oct. 2009.

JACKSON, Robert H. Quasi-states: Sovereignty, International Relations and the Third World. Cambridge, UK: Cambridge University Press, 1993.

JARQUE, Carlos M.; QUENAN, Carlos. América Latina y la diplomacia de cumbres. Madrid: Secretaría General Iberoamericana, 2009.

KAHLER, Miles; LAKE, David A. Economic Integration and Global Governance: Why so Little Supranationalism? In: MATTLI, W.; Woods, N. (Ed.). The Politics of Global Regulation. Princeton, NJ: Princeton University Press, 2009. p. 242-275.

KATZENSTEIN, Peter J. A World of Regions: Asia and Europe in the American imperium. Ithaca, NY: Cornell University Press, 2005.

KECK, Margaret E.; SIKKINK, Kathryn. Activists beyond Borders: Advocacy Networks in International Politics. Ithaca, NY: Cornell University Press, 1998.

KRASNER, Stephen D. Sovereignty: Organized Hypocrisy. Princeton, NJ: Princeton University Press, 1999.

LAKE, David A. Rightful Rules: Authority, Order, and the Foundations of Global Governance. International Studies Quarterly, v. 54, n. 3, p. 587-613, 2010 .

LEGLER, Thomas. El perfil del multilateralismo latinoamericano. Foreign Affairs Latinoamérica, v. 10, n. 3, p. 2-5, 2010a.

Gobernanza regional: El vínculo multilateral. Foreign Affairs Latinoamérica, v. 10, n. 3, p. 18-23, 2010 b. 
Post-hegemonic Regionalism and Sovereignty in Latin America: Optimists, Skeptics...

. De la afirmación de la autonomía a la gobernanza autónoma: el reto de América Latina y el Caribe. In: ROJAS ARAVENA, F. (Ed.). América Latina y el Caribe: multilateralismo vs. soberanía. La construcción de la comunidad de Estados Latinoamericanos y Caribeños. Buenos Aires: Teseo-FLACSO, 2011. p. 23-48.

. The Shifting Sands of Regional Governance: The Case of Inter-American Democracy Promotion. Politics and Policy, v. 40, n. 5, p. 848-870, 2012.

; SANTA-CRUZ, Arturo. El patrón contemporáneo del multilateralismo latinoamericano. Pensamiento Propio, n. 33, p. 11-34, Jan.-Jun. 2011.

MACDONALD, Laura; RÜCKERT, Arne. Post-neoliberalism in the Americas. New York: Palgrave Macmillan, 2009.

MALAMUD, Andrés. Overlapping Regionalism, no Integration: Conceptual Issues and the Latin American Experiences. In: EUI Working Paper RSCAS 2013/20. Florence: European University Institute, 2013.

; GARDINI, Gian Luca. Has Regionalism Peaked? The Latin American Quagmire and Its Lessons. The International Spectator, v. 47, n. 1, p. 116-133, 2012.

MERKE, Federico. Neither Balance nor Bandwagon: South American International Society Meets Brazil's Rising Power. Paper prepared for the Sixth Regional Powers Network Conference, "Rising Powers and Contested Orders in the Multipolar System.” Rio de Janeiro: PUC-Rio, 19-20 Sep. 2013.

OHMAE, Kenichi. The Rise of the Region State. Foreign Affairs, v. 72, n. 2 p. 78-87, 1993.

PETRAS, James. The New Development Politics: The Age of Empire Building and New Social Movements. Aldershot: Ashgate Publishing, Ltd., 2003.

PHILPOTT, Daniel. Revolutions in Sovereignty: How Ideas Shaped Modern International Relations. Princeton, NJ: Princeton University Press, 2001.

RADCLIFFE, Sarah A. Development, the State, and Transnational Political Connections: State and Subject Formations in Latin America. Global Networks, v. 1, n. 1, p. 19-36, 2001.

RIGGIROZZI, Pía. Region, Regionness and Regionalism in Latin America: Towards a New Synthesis. New Political Economy, v. 17, n. 4, p. 421-443, 2012. 


\section{Thomas Legler}

; TUSSIE, Diana. The Rise of Post-Hegemonic Regionalism in Latin America. In RIGGIROZZI, P.; TUSSIE, D. (Ed.). The Rise of Post-Hegemonic Regionalism. Dordrecht: Springer, 2012. p. 1-16.

RIVAROLA PUNTIGLIANO, Andrés. "Geopolitics of Integration" and the Imagination of South America. Geopolitics, v. 16, n. 4, p. 846-864, 2011.

; BRICEÑO-RUIZ, José. Introduction: Regional Integration - Linking Past and Present. In: RIVAROLA PUNTIGLIANO, A.; BRICEÑO-RUIZ, J. (Ed.). Resilience of regionalism in Latin America and the Caribbean: Development and Autonomy. New York: Palgrave Macmillan, 2013. p. 1-18.

RODRIK, Dani. The Globalization Paradox: Why Global Markets, States, and Democracy Can't Coexist. Oxford, UK: Oxford University Press, 2011.

ROJAS ARAVENA, Francisco. Rol y evaluación de la diplomacia de cumbres. Construyendo el multilateralismo cooperativo. In: ROJAS ARAVENA, F. (Ed.). Multilateralismo: perspectivas latinoamericanas. Caracas: FLACSO-Chile/Editorial Nueva Sociedad, 2000. p. 13-53.

. La CELAC y la integración latinoamericana y caribeña. Principales claves y desafíos. Nueva Sociedad, n. 240, p. 16-27, 2012.

; MILET, Paz. Diplomacia de cumbres: el multilateralismo emergente del siglo XXI. Santiago: FLACSO Chile, 1998.

ROSENAU, James N. Governance in a New Global Order. In: HELD, D.; MCGREW, A. (Ed.). Governing Globalization: Power, Authority and Global Governance. Cambridge, UK: Polity, 2002. p. 70-86.

RUEDA-JUNQUERA, Fernando. ¿Qué se puede aprender del proceso de integración europeo? Nueva Sociedad, v. 219, p. 59-75, 2009.

SANAHUJA, José Antonio. La construcción de una región: Suramérica y el regionalismo posliberal. In: CIENFUEGOS, M.; SANAHUJA, J. A. (Ed.). Una región en construcción. UNASUR y la integración en América del Sur. Barcelona: Fundación CIDOB, 2010. p. 87-134.

Post-liberal Regionalism in South America: The Case of UNASUR. In: Working Paper RSCAS 2012/05. Florence: European University Institute, 2012 .

SCHINKEL, Willem. Globalization and the State: Sociological Perspectives on the State of the State. New York: Palgrave Macmillan, 2009. 
Post-hegemonic Regionalism and Sovereignty in Latin America: Optimists, Skeptics...

SERBIN, Andrés. De despertares y anarquías. Foreign Affairs Latinoamérica, v. 10, n. 3, p. 6-11, 2010.

. Regionalismo y soberanía nacional en América Latina: los nuevos desafíos. In: ROJAS ARAVENA, F. (Ed.). América Latina y el Caribe: multilateralismo vs. soberanía. La construcción de la Comunidad de Estados Latinoamericanos y Caribeños. Buenos Aires: Teseo/FLACSO, 2011. p. 49-98.

. Déficit democrático y participación ciudadana en el marco del regionalismo post-liberal. In: Anuario de la Integración Regional de América Latina y el Gran Caribe. Buenos Aires: CRIES, 2012a.

. New Regionalism and Civil Society: Bridging the Democratic Gap. In: RIGGIROZZI, P.; TUSSIE, D. (Ed.). The Rise of Post-hegemonic Regionalism: The Case of Latin America. Dordrecht: Springer, 2012b.

SIKKINK, Kathryn. Re-conceptualizing Sovereignty in the Americas: Historical Precursors and Current Practices. Houston Journal of International Law, v. 19, p. 705-729, 1996.

STIGLITZ, Joseph E. Making Globalization Work. New York: WW Norton \& Company, 2007.

STRANGE, Susan. Mad Money: When Markets Outgrow Governments. Ann Arbor: University of Michigan Press, 1998.

TORO, Alfredo. El ALBA como instrumento de "soft balancing". Pensamiento Propio, n. 33, p. 159-184, Jan.-Jun. 2011.

TUSSIE, Diana. Latin America: Contrasting Motivations for Regional Projects. Review of International Studies, v. 35, n. 1, p. 169-188, 2009.

VAN KLAVEREN, Alberto. Political Globalization and Latin America: Toward a New Sovereignty? In: TULCHIN, J. S.; ESPACH, R. H. (Ed.). Latin America in the New International System. Boulder, CO: Lynne Rienner, 2001. p. 117-140.

VOLPI, Jorge. El insomnio de Bolívar: cuatro consideraciones intempestivas sobre América Latina en el siglo XXI. México: Debate, 2009.

WEISS, Linda. The Myth of the Powerless State. Ithaca, NY: Cornell University Press, 1998. 


\title{
Abstract
}

\section{Post-hegemonic Regionalism and Sovereignty in Latin America: Optimists, Skeptics, and an Emerging Research Agenda}

\begin{abstract}
A scholarly debate is emerging on how recent regional trends in Latin America and South America have impacted the meanings and practices of sovereignty. This debate pits two groups engaged in regionalist analysis against each other: the optimists and the skeptics. Optimists argue that recent changes in regionalism are having a transformative impact on sovereignty. Skeptics acknowledge that changes in regionalism have occurred, but that they have been accompanied by persistent and traditional sovereignty meanings and practices. The article employs a tripartite conception of sovereignty regime-sovereign, space, and authority-to sketch the parameters of the debate. Given the recent origins of ALBA, CELAC, and UNASUR, as well as the post-hegemonic regionalism which they reflect and promote, this debate can only be resolved through ambitious qualitative empirical research, especially in South America, the regional experience upon which many of the contending claims are made. Such a research agenda on the regionalism-sovereignty nexus has both significant theoretical and practical implications for understanding Latin America's and South America's unique regional, institutional, and sovereignty patterns, as well as the limits and possibilities for regional governance.
\end{abstract}

Keywords: Regionalism - Sovereignty - Regional Governance - Latin America - South America 